\title{
Survival of Swietenia macrophylla seeds sown into slash-and-burn fields in Quintana Roo, Mexico
}

Patricia Negreros-CASTILlo ${ }^{1}$

Imelda MARTíneZ-SALAZAR ${ }^{1}$

Kenneth F. KELLNER ${ }^{2}$

Carl W. MIZE ${ }^{3}$

Robert K. SWIHART ${ }^{2}$

María Angélica NAVARRo-MARTínez ${ }^{4}$

${ }^{1}$ Universidad Veracruzana

Instituto de Investigaciones Forestales

Xalapa, CP 91000, Veracruz

Mexico

2 Purdue University

Department of Forestry

and Natural Resources

IN 47907 West Lafayette

USA

${ }^{3}$ Iowa State University

Department of Natural Resource

Ecology and Management

IA 50011, Ames

USA

${ }^{4}$ Colegio de la Frontera Sur

CP 77014, Chetumal

Quintana Roo

Mexico

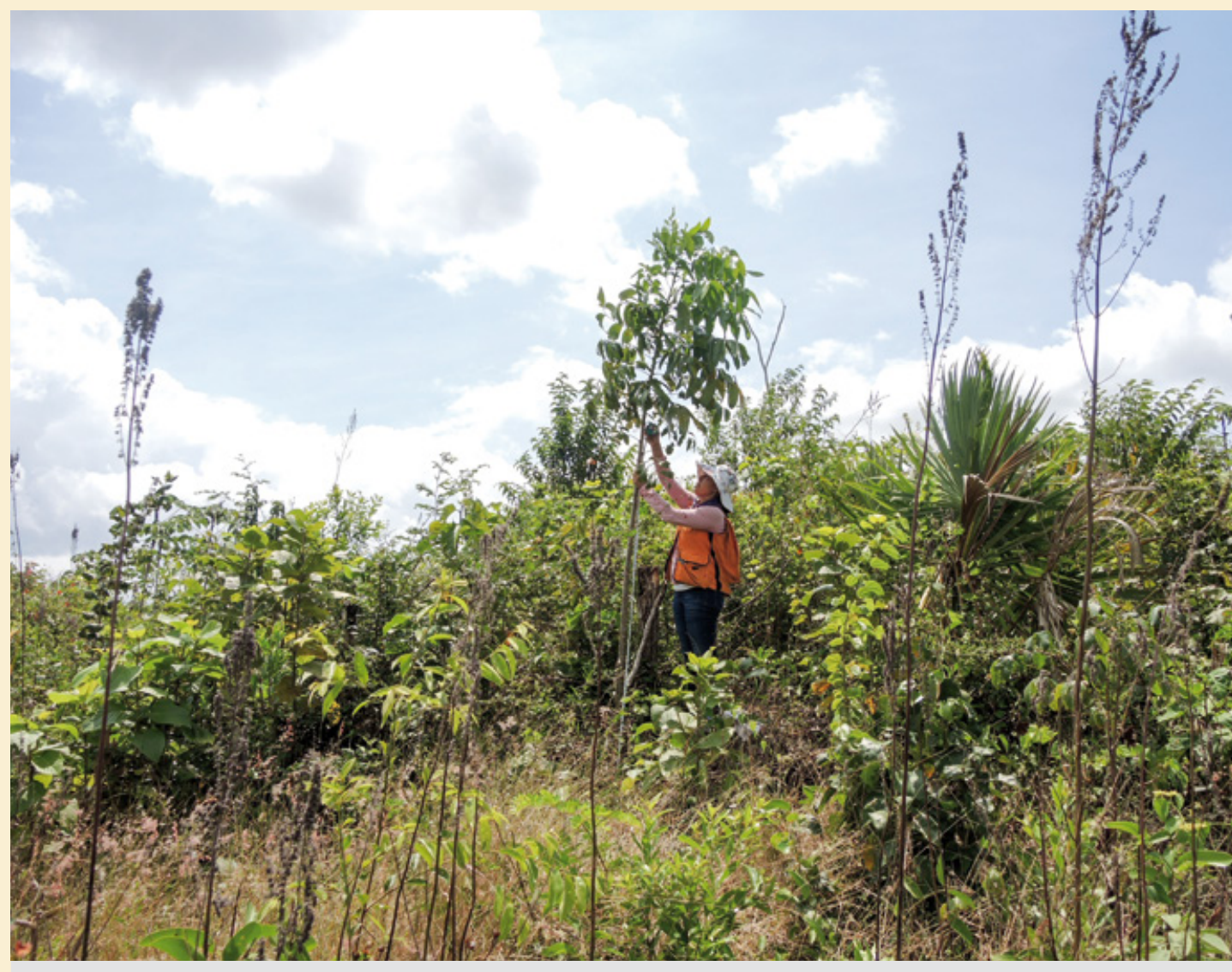

Photo 1.

Well established mahogany sapling (held by a person) in an abandoned slash-and-burn agriculture (SBA) field. Photo P. Negreros-Castillo. 


\section{RÉSUMÉ}

\section{SURVIE DES SEMENCES DE SWIETENIA MACROPHYLLA SEMÉES SUR BRÛLIS DANS L'ÉTAT DE QUINTANA ROO AU MEXIQUE}

En Amérique tropicale, la régénération de l'acajou à grandes feuilles, Swietenia macrophylla King, essence commerciale majeure, est problématique en raison de ses caractéristiques de fructification et de dispersion et de sa faible tolérance à l'ombre et sa réaction à l'exploitation forestière. Dans l'État de Quintana Roo, au Mexique, les brûlis abandonnés offrent d'excellents espaces pour l'établissement de jeunes plants, mais un moyen efficace permettant d'assurer la survie des semences reste à identifier. La présente étude s'est attachée à évaluer la probabilité de prédation des semis directs d'acajou, en analysant les effets de trois types de traitement (quatre types de protection des semences, deux méthodes de semis et deux moments de semis dans la journée). Le pourcentage moyen de semences éliminées ou consommées en partie sur une période de 12 heures varie de 1,1 à $7,7 \%$ selon les quatre types de traitement des semences mais ne varie pas selon les deux méthodes de semis. La précipitation au moment du semis est fortement positive pour la reprise des semences, tandis que la température journalière minimale a un effet légèrement négatif. L'effet de la date des semis, selon le calendrier julien, est positif pour la survie des semences. La prédation des semences ne varie pas selon les traitements de protection qui permettent l'accès aux seuls rongeurs, aux seuls insectes et aux deux, et la prédation est plus importante avec ces trois types de traitement qu'avec le traitement interdisant totalement l'accès aux prédateurs. La prédation des semences n'est pas influencée par le moment du semis dans la journée. Le semis direct est favorable à la régénération de l'acajou, notamment lorsque les semences sont trempées pendant au moins deux semaines avant le semis pour réduire les risques de prédation et augmenter les chances de survie et de reprise.

\section{Mots-clés : Swietenia macrophylla,} acajou, régénération, sylviculture, forêt tropicale, prédation des semences, Mexique.
ABSTRACT

\section{SURVIVAL OF SWIETENIA MACROPHYLLA SEEDS SOWN IN SLASH-AND-BURN FIELDS IN QUINTANA ROO, MEXICO}

In tropical America, regeneration of bigleaf mahogany, Swietenia macrophylla King, the most important commercial tree species, is problematic because of its fruiting and dispersal characteristics, very low tolerance of shade and response to logging. In Quintana Roo, Mexico, abandoned slash-and-burn cropfields are excellent candidates for seedling establishment, but an efficient way to establish mahogany seedlings has not been identified. This study assessed the probability of predation on directly sown mahogany seeds, examining the effects of three treatments (four types of seed protection, two sowing methods, two times of day for sowing). The mean percentage of seeds either partially consumed or removed during a 12-hour period varied from 1.1 to $7.7 \%$ among the four seed protection treatments and did not differ between the two sowing methods. Precipitation had an important positive effect on survival, and minimum daily temperature had a marginal negative effect on survival. The Julian calendar date had a positive effect on seed survival. Seed predation did not differ among the seed protection treatments that allowed access only to rodents, only to insects, and to both types of seed predators, and predation was greater with these three treatments than with the no-access treatment. Seed predation was not influenced by the time of day of sowing. Direct sowing offers a good option for regenerating mahogany, especially if the mahogany seeds are soaked for at least 2 weeks before sowing to reduce predation risks and increase prospects for seed survival and seedling establishment.

\section{Keywords: Swietenia macrophylla,} mahogany, regeneration, silviculture, tropical forest, seed predation, Mexico.

\section{SUPERVIVENCIA DE SEMILLAS DE SWIETENIA MACROPHYLLA SEMBRADAS EN CAMPOS DE CORTE Y QUEMA EN QUINTANA ROO, MÉXICO}

En América tropical, la regeneración de la caoba de hoja grande, Swietenia macrophylla King, especie comercial de grandísima importancia, presenta dificultades por sus características de fructificación y dispersión, su escasa tolerancia a la sombra y al aprovechamiento forestal. Las áreas de cultivo de corte y quema abandonadas en el Estado mexicano de Quintana Roo son excelentes espacios para el establecimiento de plántulas de caoba, pero aún no se ha encontrado un medio eficaz para garantizar la supervivencia de las semillas. Este estudio evaluó la probabilidad de depredación en siembras directas de caoba analizando tres tipos de tratamiento: cuatro tipos de protección de semillas, dos métodos de siembra y dos momentos de siembra en el día. El porcentaje promedio de semillas eliminadas o parcialmente consumidas en un período de 12 horas varía de 1.1 a $7.7 \%$, dependiendo de los cuatro tipos de tratamiento de protección, pero no varía según los dos métodos de siembra. La precipitación durante la siembra tuvo un importante efecto positivo en la supervivencia, mientras que la temperatura diaria mínima tuvo un efecto ligeramente negativo. El efecto de la fecha de siembra, según el calendario juliano, fue positivo para la supervivencia de las semillas. La depredación de semillas no varía entre tratamientos que permiten el acceso sólo a roedores, sólo a insectos, o a ambos; la depredación es mayor con estos tres tipos de tratamiento que con el tratamiento que impide totalmente el acceso a los depredadores. La depredación de semillas no se vio influida por la hora del día en que se sembraron. La siembra directa es favorable para la regeneración de la caoba, especialmente cuando se remojan las semillas al menos durante dos semanas antes de la siembra para reducir los riesgos de depredación y aumentar las posibilidades de supervivencia y crecimiento.

Palabras clave: Swietenia macrophylla, caoba, regeneración, silvicultura, bosque tropical, depredación de semillas, México. 


\section{Introduction}

A main challenge for silviculturists managing natural tropical forests for timber production is to ensure regeneration of commercially valuable timber species. Adequate regeneration is needed to assure sufficient merchantable trees for a subsequent commercial harvest (Smith et al., 1997). Silviculturists who manage tropical forests for timber production in the Yucatan Peninsula face additional challenges, such as maintaining levels of tree biodiversity in ecosystems with few commercially valuable species, low growth rates of commercial species, logistical difficulties related to accessing managed areas, regimes of severe natural disturbances, and multiple uses of the forest by local inhabitants (Dawkins and Philip 1998). Basic ecological knowledge of commercially important species is also essential for the development of any regeneration technique (Smith et al., 1997) and is lacking for most species in the Yucatan Peninsula.

Throughout tropical America, big leaf mahogany (Swietenia macrophylla King) is the most important tree species commercially. Mahogany is so important that it could be considered a "financial" keystone species. When forests in some countries do not, or no longer contain commercial species, they are more likely to be converted to pasture or other, more profitable land uses (Fredericksen and Putz, 2003). Thus, mahogany's presence encourages landowners to manage their forests for timber production rather than convert them to other uses (senior author, personal observation in Quintana Roo, Mexico) (photo 1).

Mahogany seedlings require high light levels and are intolerant of competition for light from other plants (Negreros-Castillo et al., 2003). Within its geographic range many types of natural disturbances create appropriate conditions for mahogany to regenerate (Brown et al., 2003). In Quintana Roo (the state on the eastern side of the Yucatan Peninsula), Mexico, Snook (1993) argued that mahogany regenerates after hurricanes that strike the Peninsula. As the most common hurricane impacts are breakage of large branches, defoliation of tree crowns, and windthrow of trees, hurricanes reduce shading and create canopy openings (Meléndez-Ackerman et al., 2003). The forest floor, however, is covered by a thick layer of leaves and broken branches, and a dense understorey quickly forms from surviving plants and sprouts. Under such conditions, mahogany seeds and seedlings have very low survival and growth rates (Negreros-Castillo et al., 2003). In contrast, fire, which usually occurs after a hurricane, creates exceptional site conditions for regeneration of mahogany and other important commercial species (Negreros-Castillo et al., 2003; Sorenson, 2006). Mature mahogany trees above $35 \mathrm{~cm} \mathrm{DBH}$ are resistant to windthrow and damage by fires and, thus, are likely to shed seeds that will germinate and produce seedlings in burnt areas (Negreros-Castillo et al., personal observation).

Compared with hurricanes, for more than 3,000 years slash and burn agriculture (SBA) has been a far more frequent and spatially distributed disturbance in the Maya forest region where mahogany grows (Ford and Nigh, 2010). In SBA, farmers clear one to two ha of forest, cultivate them

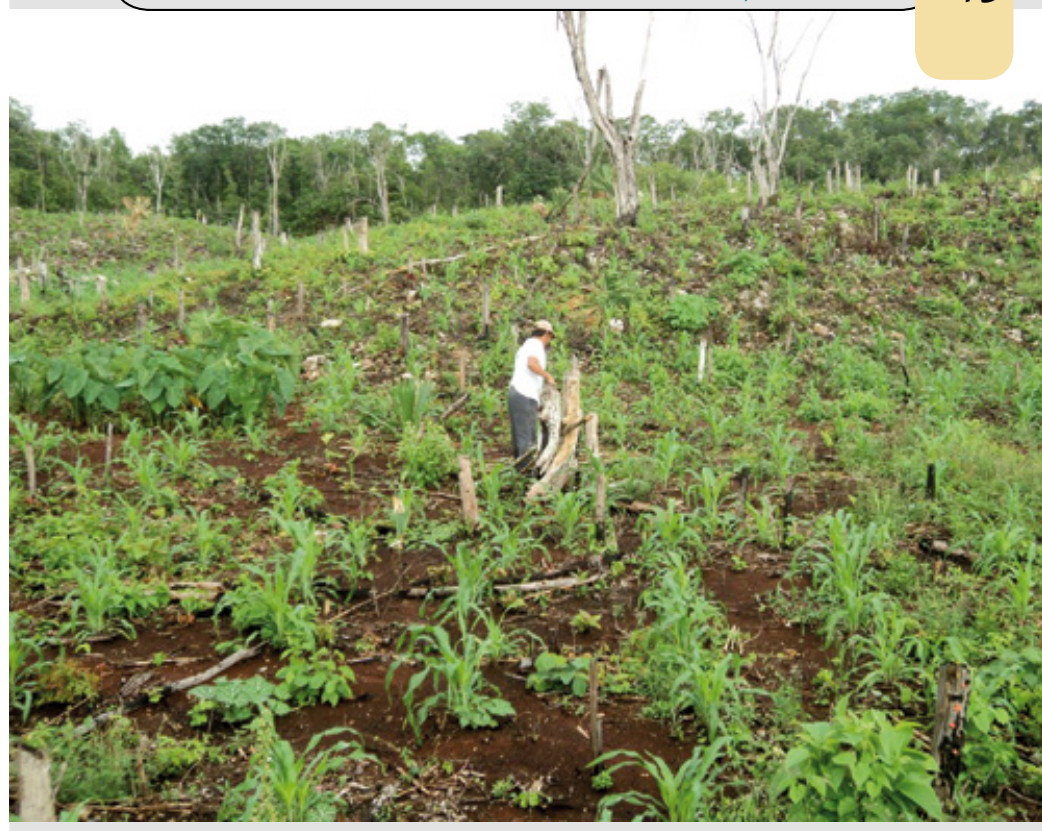

Photo 2.

Typical condition of an SBA field 1 to 2 months

after seeding corn.

Photo P. Negreros-Castillo.

for about three years, and then abandon them for 7 to 12 years, which allows natural secondary succession and forest reestablishment. In the tropical forests of Quintana Roo, abandoned SBA fields provide an ideal soil substrate for seeds from mature mahogany trees (if present). Mahogany seeds that land in these fields can germinate and start growing rapidly, giving them an advantage over other species (Negreros-Castillo and Mize, 2003). Consequently, mahogany populations in Mexican portion of the Yucatan Peninsula exhibit strong spatial correlations in their size distributions because of the patchy nature of suitable regeneration conditions in time and space created by abandoned SBA fields (Negreros-Castillo and Mize, 2003).

SBA fields might be excellent sites for sowing or planting mahogany (Negreros-Castillo et al., 2003). Specifically, during the last year of cropping (usually the third), mahogany could be sown or planted when corn (Zea mays) is sown. Mahogany seedlings should grow well and have high survival rates, because farmers control weeds to protect crops (photo 2), and the corn stalk and residue from other crops, which are harvested late in the year, should help protect the seedlings, slow succession, and reduce competition.

For years, the primary regeneration technique for mahogany has been to plant bagged seedlings (Mayhew and Newton, 1998), but direct seeding has a significant advantage operationally because a kilogram contains about 2,000 seeds, which equals the weight of two mahogany seedlings ready for planting. As many SBA sites are far from roads, sowing seed has obvious advantages compared to planting seedlings. Additionally, under similar growing conditions, mahogany seedlings from seeds are about the same height as planted seedlings in only two years (Navarro-Cerrillo et al., 2011).

Mayhew and Newton (1998) described results of direct seeding of mahogany in various countries. The results vary from complete failure to moderately good germination and 
survival. In the Americas the practice seems to have been mostly successful, especially in drier areas. On moister sites with no weed control, planted seedlings are preferable because their initial size gives them an advantage compared to weeds, but where weeding is done, as in SBA sites, direct seeding is likely to be more successful over a wider range of site conditions (Lamb, 1966).

Nyland (2002) discussed many aspects of direct sowing and listed several factors that affect germination and early survival. For sowing into a SBA field, desiccation after germination, infection by fungi, and consumption or damage by seed predators lower mahogany recruitment. Of these, predation is a major concern directly related to sowing (Janzen, 1971).

Seed predation by vertebrates (mostly rodents and some birds) and insects can substantially impact a plant's ability to successfully recruit members into its population, with important implications for forest stand dynamics (Nopp-Mayr et al., 2012). Whether a forager consumes, stores, or ignores an encountered seed depends on environmental context. The forager's physiological state, the

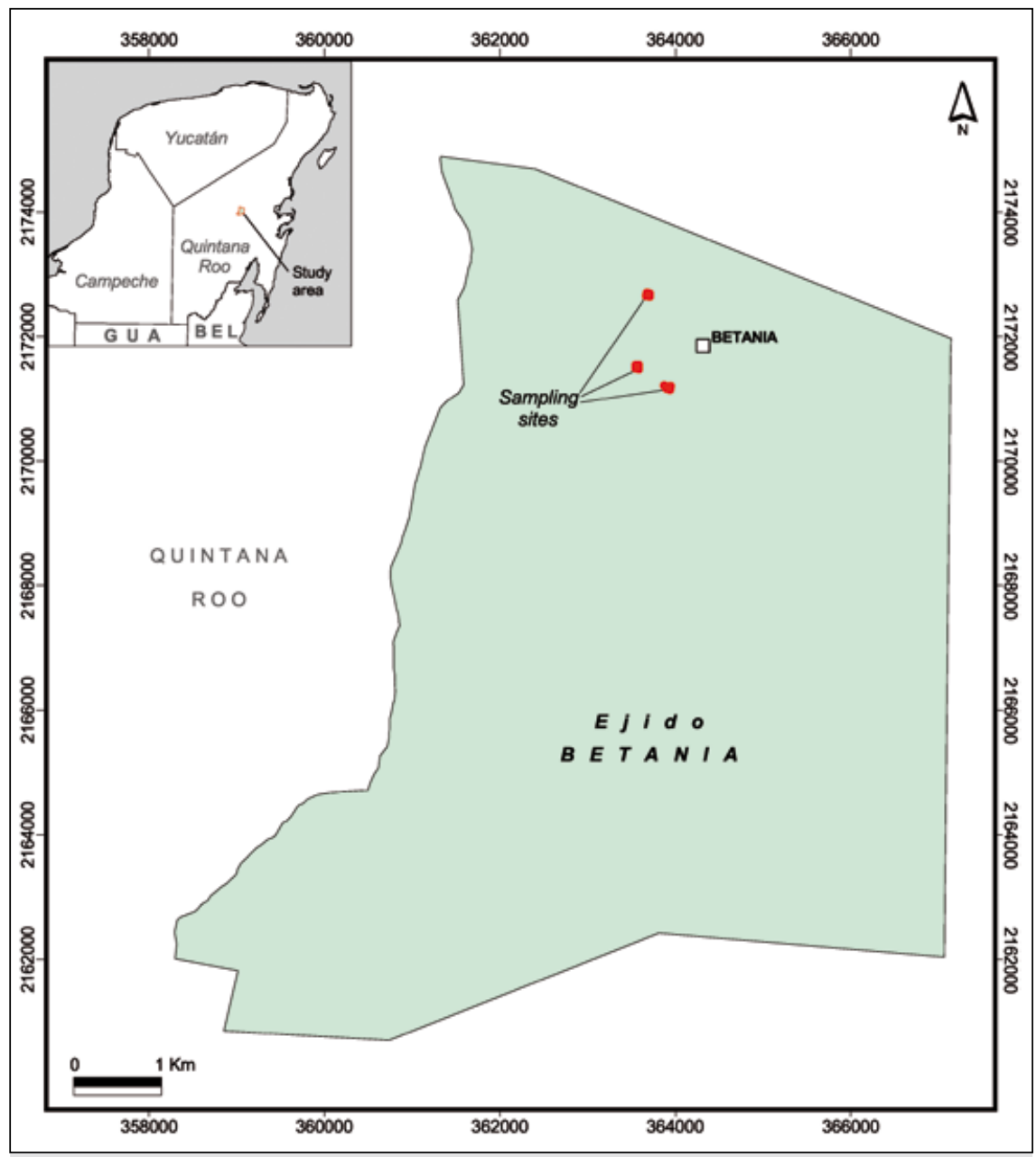

Figure 1.

Location of the community (ejido) of Betania and experimental blocks, Quintana Roo, Mexico.

riskiness of the site, attributes of the seed that influence its perceived nutritional value, the relative availability of other food, and canopy cover can influence a seed's fate (Fedriani and Manzaneda, 2005; Norghauer and Newbery, 2011). The cumulative effect of such context-dependent decisions on plant regeneration can vary from detrimental to beneficial (Lichti et al., 2014), which is consistent with studies of regeneration and seed predation in tropical forests (Cole, 2009). Unfortunately, studies on seed predation of commercially valuable tropical timber species in the Yucatan Peninsula are scarce (Gutiérrez-Granados et al., 2011).

In this study we evaluated the impact of predation on directly sown mahogany. Specifically, we quantified the survival of mahogany seed sown under varying types of seed protection, method of seed sowing, and time of day in SBA fields. This study is part of a larger research project to develop a silvicultural system for mahogany in Yucatan forests that maintains a high level of biodiversity in an economically profitable operation.

\section{Materials and Methods}

\section{Study area}

The study was conducted in the state of Quintana Roo, Mexico, located on the eastern side of the Yucatan Peninsula. The forests of Quintana Roo are part of the Maya forest region and represent the largest continuous block (1.5 million hectares) of tropical forest in Mexico (INEGI, 2013). Central and southern Quintana Roo forests are classified as seasonal tropical forests, the most important type of tropical forest in Central America. Brosimum alicastrum (ramón blanco) and Manilkara zapota (chicozapote) are the most abundant tall trees (Pennington and Sarukhán, 2005). Hurricanes, fires, and SBA activities have had important effects on the vegetation for centuries (Edwards, 1986). The climate is classified as Aw, which is defined as warm and submoist with abundant rains in summer and dry winters by the Köppen classification system, modified by García (1973). Annual rainfall is about 1,200 mm, usually falling between June and October (INEGI, 2013), with a five to six months dry season when rainfall is less than $45 \mathrm{~mm} /$ month. Soils are derived from limestone, and Rendolls is the most common type (Bautista and Zinck, 2010). The topography is relatively flat with a rolling profile that creates manifold micro soil-site conditions (INEGI, 2013).

The study was established in 2012 in a forest owned by the community of Betania, located near the center of Quintana Roo (figure 1). Betania owns 10,800 ha of tropical forest of which 5,000 ha are under commercial timber management and 5,800 ha are under SBA management. The community has commercially managed its forest since 1985 . 


\section{Experimental design}

Three farmers in Betania, each with a SBA field that was in its last year of use for production of corn and other crops and that would not be farmed for at least 10 years, agreed to participate. The three SBA fields, which serve as experimental blocks called SBA1, SBA2, and SBA3, were at least $500 \mathrm{~m}$ apart and surrounded by secondary vegetation that was about $18 \mathrm{~m}$ tall and $16-18$ years old. For each field, minimum distance to the adjacent forest was recorded as the shortest distance between the forest edge and any part of the $50 \times 50 \mathrm{~m}$ plot in the field. Daily minimum temperature (C) and precipitation $(\mathrm{mm})$ data for the study were obtained from the Felipe Carrillo Puerto government weather station near the research site.

The experimental design was a $4 \times 2 \times 2$ factorial with 4 types of seed protection, 2 sowing depths, and 2 times of day for sowing for a total of 16 combinations. The 16 combinations were replicated twice a day for 15 sample days in each of the 3 fields yielding a total sample size of 1,440. The four types of seed protection were achieved by using three types of cages that resulted in different levels of access to the seeds: i) no predators had access (NA), ii) only rodents had access (RA), iii) only insects had access (IA); and no cage, which allowed total access to all predators (TA). The seed sowing methods were $i$ ) soil surface (S) and $i$ ) buried in the soil (B). Sowing occurred $i$ ) at $06 \mathrm{~h} 00$ with seed fates recorded at $18 \mathrm{~h} 00$ and $i$ ) at $18 \mathrm{~h} 00$ with seed fates recorded at 06 h00 the next day.

A split plot design was used for the spatial layout with time of sowing as the whole plots and the eight combinations of the four seed protection treatments (NA, RA, IA, TA) and two sowing methods $(S, B)$ as the subplots. In each of the three blocks (SBA1, SBA2, and SBA3), a north-south oriented $50 \mathrm{~m} \times 50 \mathrm{~m}$ area, near the center of the block, was used as the sowing area. Eleven east-west oriented parallel lines, spaced $5 \mathrm{~m}$ apart, were established on each sowing area. Due to a limited number of cages for seed protection, the study was conducted one block at a time. For three days two complete treatment replicates were separately established in the morning and in the evening. After three days at one block, the process was repeated at another block, and after three more days, the remaining block was treated. This cycle was repeated five times, which yielded 15 days of observations in each block. The first sowing was at the beginning of the rainy season, on July 19,2012 , and the final one was on September $3^{\text {rd }}$, 2012. In all, 7,200 mahogany seeds were utilized. Measuring predation every 12 hours allowed a comparison of circadian effects, as well as variation due to the influence of daily precipitation and minimum daily temperature. Because the study spanned 43 days, we also were able to examine seasonal effects on seed survival (see Analysis).

Seeds were collected from capsules in the crowns of good quality mahogany trees from a commercially managed forest $10 \mathrm{~km}$ from Betania in March 2012 and stored in paper bags in a refrigerator $\left(\right.$ above $0^{\circ} \mathrm{C}$ ). Seeds were not moistened before being sown with bare hands.

The eight treatment combinations of four types of seed protection and two sowing methods were randomly assigned
BOIS ET FORÊTS DES TROPIQUES, 2016 , N³29 (3) SURVIE DES SEMENCES DE SWIETENIA MACROPHYLLA / LE POINT SUR,

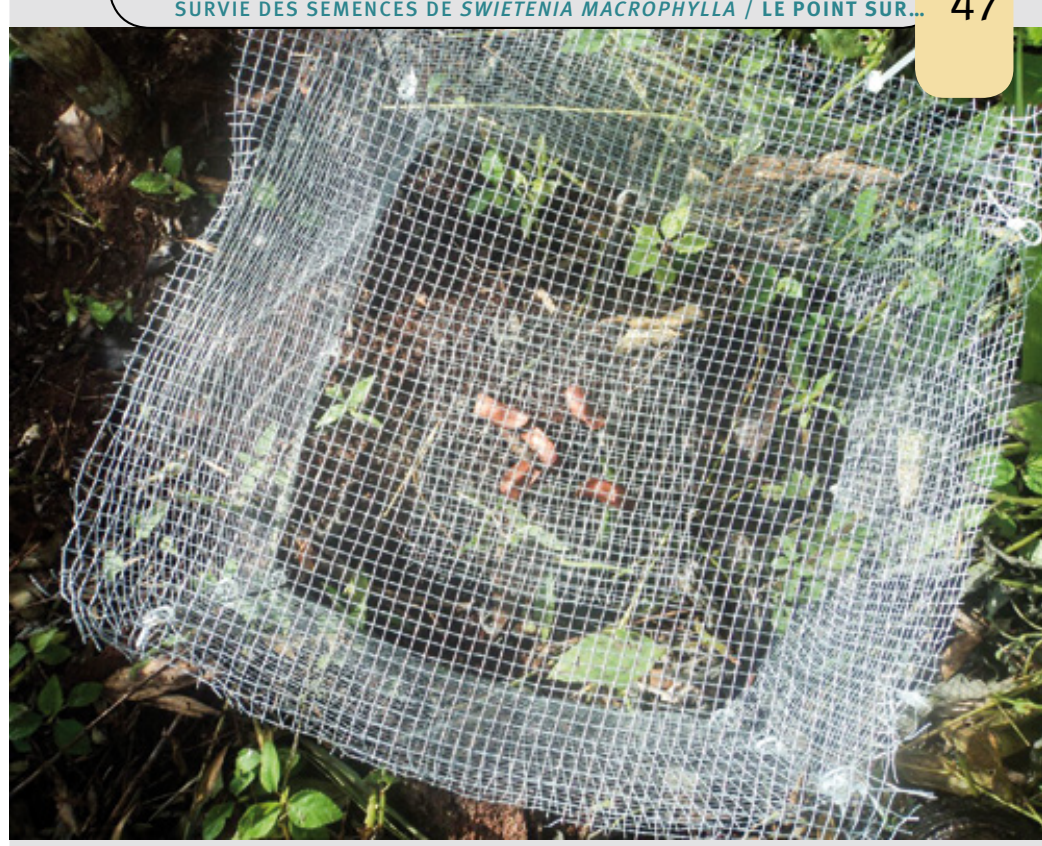

Photo 3.

Mahogany seed on mesh in a cage

for the no access (NA) treatment

Photo P. Negreros-Castillo.

to subplots every $20 \mathrm{~m}$ along the 11 parallel lines in each block. Each day the starting site of the treatments was $20 \mathrm{~m}$ ahead of the last one for the previous set of subplots (morning or night). At each subplot five seeds were sown in a circular pattern with about $4 \mathrm{~cm}$ between adjacent seeds (approximately a $7 \mathrm{~cm}$ diameter circle). For three of the seed protection treatments (NA, RA, and IA), a $25 \mathrm{~cm} \times 25 \mathrm{~cm} \times 15 \mathrm{~cm}$ wire cage was placed over the seed, and for the fourth treatment (TA) nothing was placed over the seed. The aperture of the screen mesh was $3 \mathrm{~mm}$ for NA, $2 \mathrm{~cm}$ for RA, and $1 \mathrm{~cm}$ for IA) (photo 3). For the RA treatment, a continuous band of "Tree Tanglefoot insect barrier" (Contech, Inc.) was spread around the trap to keep insects from getting to the seed. For the surface sowing method (S), seeds were placed on a $25 \mathrm{~cm} \times 25 \mathrm{~cm}$ piece of wire mesh with $3 \mathrm{~mm}$ apertures laid on the soil surface, and for the buried sowing method (B) seeds were buried $3 \mathrm{~cm}$ deep in the soil with no wire mesh used. At the time of sowing there were no weeds in the subplots, as the farmers had cleared the area as part of their cultivation for corn, and seeds from other species were not visible. At the end of each 12-hour cycle, each seed was categorized as i) intact and present, ii) removed or missing, or iii) partially consumed.

\section{Analysis}

The standard errors of the mean for partially consumed seed were calculated via analysis of variance of all treatments. The variation in removed and in partially consumed seed plus removed seed within the no-access treatment (NA) was much smaller than the variation within the other three seed protection treatments, so the standard errors were estimated by doing separate analyses of the NA treatment and of the RA, IA, and TA treatments, respectively. The standard error for means for the time of day of sowing was calculated from the analysis of all treatments). 
The response variable analyzed was the number of seeds, out of a total of 5 in each subplot $(n=1,440)$, which remained intact at the conclusion of a 12-hour trial period. Thus, we developed a binomial regression model where the probability of mahogany seeds survival was the parameter of interest. Covariates on probability of survival included Julian date of the trial, enclosure type (NA, RA, IA, TA), sowing method (seed buried or on the surface), block (SBA field), daily precipitation, and minimum daily temperature. For precipitation and temperature, only daily (i.e., 24 hour) data were available, so both diurnal and nocturnal 12-hour periods within each day were assigned the same weather covariate values. All covariates were standardized to have a mean of 0 and a variance of 1 before analysis and considered as fixed effects.

The model was fit in a Bayesian framework using Program JAGS (Plummer, 2003) called from within R (R. Core Development Team, 2013) using the library R2jags (Su and Yajima, 2012). JAGS uses Markov chain Monte Carlo (MCMC) simulations to draw from the joint posterior distribution of all model parameters. We used uninformative priors on the model intercept (uniform distribution from -10 to 10) and covariate effects (normal distributions with mean 0 and standard deviation 100). Posterior distributions were based on five parallel MCMC chains of length 8,000 iterations, with a burn-in of 4,000 iterations and a thinning rate of 20 . Convergence of posterior distributions was determined for all parameters in the resulting models using the Gelman-Rubin convergence criterion, R-hat (Brooks and Gelman, 1998). R-hat values $\leq 1.1$ were considered acceptable (Gelman and Hill, 2007). A posterior predictive check was conducted with Pearson residuals and used to estimate model goodness-of-fit with a Bayesian p-value (Gelman et al., 1996). Parameters with $95 \%$ credible intervals (based on their posterior distributions) that did not overlap 0 were considered statistically significant.

\section{Results}

The mean percentages of partially consumed seeds and removed seeds during a 12 -hours period varied from 0.9 to $2.6 \%$ and from 0.2 to $6.2 \%$ among the four seed protection treatments, respectively (table I). The no-access treatment (NA) was more effective at keeping predators from removing seeds $(0.2 \%)$ than it was at keeping predators from partially consuming seeds (0.9\%).

We obtained a Bayesian p-value of 0.55 indicating adequate fit for the binomial regression model. The overall model-derived mean probability of seed survival within a given 12-hour trial was 0.93 . Environmental covariates affected seed survival. Precipitation had a significant positive effect on survival (table II) with a 1-standard deviation increase in daily precipitation (about $6.4 \mathrm{~mm}$ ) increasing the odds of survival by $37 \%$. Minimum daily temperature had a marginal negative effect on survival (table II) with a 1-standard deviation increase in minimum daily temperature (about $0.95^{\circ} \mathrm{C}$ ) decreasing the odds of survival by $10 \%$. Julian date had a significant positive effect on seed survival (table II) with a 1-standard deviation increase in Julian date (about 14 days) increasing odds of survival by $18 \%$. Date was uncorrelated with both precipitation $(p=0.62)$ and minimum temperature $(p=0.23)$, whereas precipitation and minimum temperature had a weak negative correlation $(r=-0.39, p<0.01)$. There was no significant difference in probability of seed survival between nocturnal and diurnal periods (table II).

Probability of mahogany seed survival also varied among seed protection treatments. Relative to the NA treatment, the other treatments allowed access to insects, rodents, and all predators, which greatly decreased the odds of seed survival (by $81 \%, 82 \%$, and $81 \%$, respectively;

Table I.

Mean percentages of seeds partially consumed, of seeds removed, and of the total of partially consumed and removed seeds among seed protection treatments during a 12-hour period, based on 360 observations, and between planting times, based on 720 observations. Value in parentheses is standard error for percentage above.

\begin{tabular}{|c|c|c|c|}
\hline $\begin{array}{l}\text { Seed protection } \\
\text { treatment }\end{array}$ & $\begin{array}{l}\text { Seeds partially } \\
\text { consumed (\%) }\end{array}$ & $\begin{array}{c}\text { Seeds } \\
\text { removed (\%) }\end{array}$ & $\begin{array}{l}\text { Seeds partially consumed } \\
\text { plus seed removed (\%) }\end{array}$ \\
\hline Total access & $\begin{array}{l}2.0 \\
(0.4)\end{array}$ & $\begin{array}{l}4.9 \\
(0.6)\end{array}$ & $\begin{array}{c}6.9 \\
(0.7)\end{array}$ \\
\hline Insects allowed & $\begin{array}{l}2.6 \\
(0.4)\end{array}$ & $\begin{array}{c}4.7 \\
(0.6)\end{array}$ & $\begin{array}{l}7.3 \\
(0.7)\end{array}$ \\
\hline Rodents allowed & $\begin{array}{l}1.5 \\
(0.4)\end{array}$ & $\begin{array}{c}6.2 \\
(0.6)\end{array}$ & $\begin{array}{l}7.7 \\
(0.7)\end{array}$ \\
\hline No predators access & $\begin{array}{c}0.9 \\
(0.1)\end{array}$ & $\begin{array}{c}0.2 \\
(0.3)\end{array}$ & $\begin{array}{c}1.1 \\
(0.3)\end{array}$ \\
\hline 6 AM Planting & $\begin{array}{c}1.3 \\
(0.3)\end{array}$ & $\begin{array}{c}4.1 \\
(0.4)\end{array}$ & $\begin{array}{c}5.5 \\
(0.5)\end{array}$ \\
\hline 6 PM Planting & $\begin{array}{c}2.1 \\
(0.3)\end{array}$ & $\begin{array}{l}3.9 \\
(0.4)\end{array}$ & $\begin{array}{c}6.0 \\
(0.5)\end{array}$ \\
\hline
\end{tabular}


Table II.

Parameter estimates from the logistic model of mahogany seed survival probability, fit in a Bayesian framework. Mean parameter values are given along with the $95 \%$ credible interval around the mean. Parameters with $95 \%$ credible intervals that did not overlap 0 were considered statistically significant and are bolded. Codes for predator exclosure treatment are as follows: NA = no access by seed predators, $I A=$ insects allowed access, $R A=$ rodents allowed access, $\mathrm{TA}=$ all predators allowed access.

\begin{tabular}{l|c|c|}
\hline Parameter & Mean & 95\% C.I. \\
$\begin{array}{l}\text { Intercept } \\
\text { Julian date }\end{array}$ & $\mathbf{4 . 0 2 4}$ & $(3.645,4.467)$ \\
\hline Precipitation & $\mathbf{0 . 1 6 9}$ & $(0.059,0.285)$ \\
\hline Min. daily temperature & $\mathbf{0 . 3 1 6}$ & $(0.165,0.491)$ \\
\hline Night effect & -0.108 & $(-0.218,0.010)$ \\
\hline Buried effect & -0.116 & $(-0.318,0.070)$ \\
\hline Exclosure Comparisons & 0.105 & $(-0.085,0.291)$ \\
\hline IA vs. NA & & \\
\hline RA vs. NA & $\mathbf{- 1 . 6 9 4}$ & $(-2.118,-1.295)$ \\
\hline TA vs. NA & $\mathbf{- 1 . 7 3 8}$ & $(-2.173,-1.326)$ \\
\hline IA vs. RA & $\mathbf{- 1 . 6 5 5}$ & $(-2.116,-1.254)$ \\
\hline IA vs. TA & 0.044 & $(-0.222,0.284)$ \\
\hline RA vs. TA & -0.039 & $(-0.292,0.235)$ \\
\hline Block Comparisons & -0.082 & $(-0.332,0.174)$ \\
\hline SBA 2 v. SBA 1 & & \\
\hline SBA 3 v. SBA 1 & $\mathbf{0 . 4 5 1}$ & $(0.189,0.680)$ \\
\hline SBA 3 v. SBA 2 & 0.069 & $(0.243,0.788)$ \\
\hline
\end{tabular}

table II, figure 2). However, the effects of the insect $(I A)$, rodent $(R A)$, and all predator access (TA) treatments on probability of seed survival did not differ from each other (table II). Seed burial also did not have a significant effect on survival, though there was a trend of higher survival for buried seeds (table I).

There was a significant effect of block (i.e., field) on probability of seed survival (table I). Post-hoc comparisons revealed significantly lower survival in SBA1 relative to SBA2 and SBA3, whereas the latter two did not differ. Although the fields were intended to be a blocking factor and not a treatment themselves, it is notable that the field with the lowest predicted seed survival probability (SBA1) was the field closest to the forest edge (figure 3 ).

\section{Discussion \& conclusion}

Seed survival is an important factor to consider in the evaluation of direct sowing as a silvicultural regeneration technique. In this study, average seed survival varied from $99 \%$ per 12 -hour period for the no-predators-allowed treatment (NA) to about 93\% for the other three seed protection treatments (RA, $I A, T A$ ) (figure 2 ). The seeds that were totally protected from predators had a significantly higher survival rate, but such protection is neither feasible nor practical. On the other hand, seed burial may be a more realistic approach for direct sowing of mahogany. In this study, buried seed had a marginal, though not statistically significant, increase in survival relative to seed sown on the soil surface. The absence of a strong effect of burial on seed predation is surprising; other studies have found strong positive effects of burial on seed survival across a range of tree species and habitats (Pérez-Ramos and Marañón, 2008). Even if burial does not increase short-term

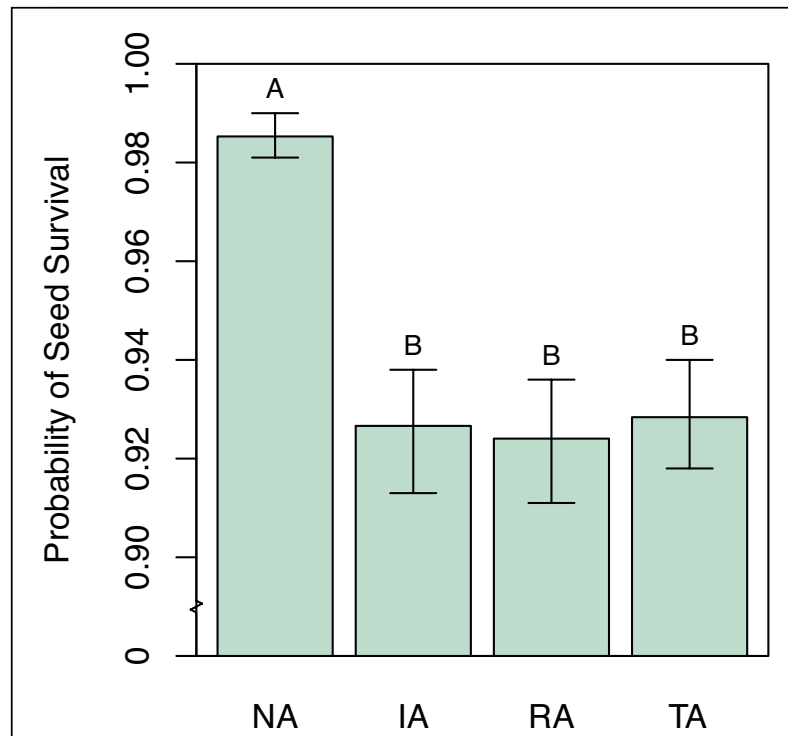

Seed Protection Treatment
Figure 2.

Comparison of probability of mahogany seed survival between exclosure treatments allowing access to different sets of seed predators (NA $=$ no predator access, $I A=$ only insects allowed access, $R A=$ only rodents allowed access, $\mathrm{TA}=$ total access by all predators). Error bars represent 95\% credible intervals around the mean. Seed protection treatments means represented by different letters are statistically different from each other. 


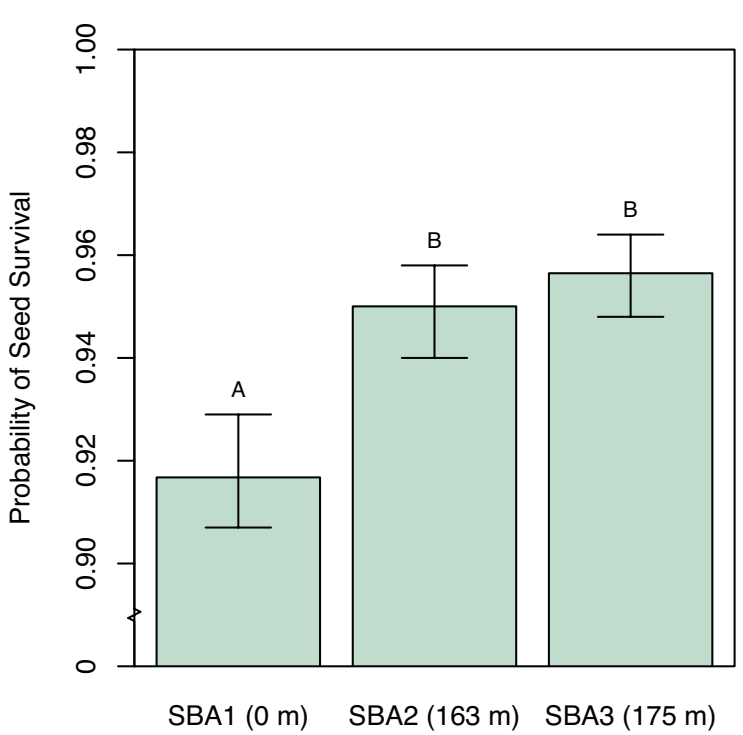

Block (Minimum Distance to Forest Edge)

Figure 3.

Comparison of probability of mahogany seed survival among the three blocks. Error bars represent $95 \%$ credible intervals around the mean. Block means represented by different letters are statistically different from each other.

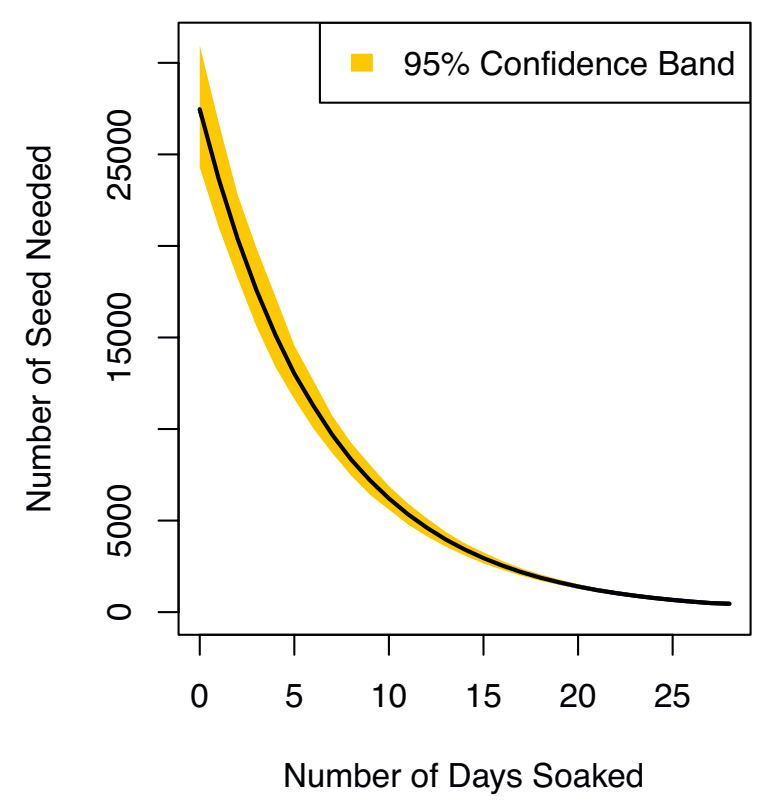

Figure 4.

Estimated number of mahogany seeds (with 95\% confidence intervals) needed to produce 100 four-year-old seedlings per hectare in relation to the number of days the seeds were soaked before sowing, based on $93 \pm 1 \%$ (mean \pm SD) seeds not consumed or removed per half day, $58 \pm 2 \%$ seed germination, and $40 \%$ survival of germinated seedlings over four years. Confidence intervals were generated based on 1,000 bootstrap simulations from the posterior distributions of seed removal probability (based on the fitted model) and germination probability (based on Negreros-Castillo et al., 2003). seed survival in mahogany, it still provides the benefit of increased germination probability relative to seeds on the soil surface (Negreros-Castillo et al., 2003).

Overall levels of seed predation, and potentially the magnitude of the impact of seed burial on survival of directly sown mahogany, can vary with habitat. Overall seed survival for unprotected seeds (93\% per 12-hour period) in this study of slash and burn fields was lower than a similar study in forests in Quintana Roo, in which 76\% of unprotected seed had been lost to predation within 60 days of sowing (equivalent to $99 \%$ survival over 12 hours; Gutiérrez-Granados et al., 2011). Other investigators have also noted strong effects of habitat differences on predation of wind-dispersed seeds by animals (Myster, 2015).

Julian date and precipitation were uncorrelated over the length of the study, and both had positive effects on survival. Increasing survival (and thus, decreased predation) over time may be the result of fewer predators as the rainy season progresses or increasing abundance of alternative food resources in the slash and burn fields and surrounding forest. Increasing precipitation might lead to lower predation if seed predators are less likely to forage while it is raining. Based on 20 years of weather data for Felipe Carrillo Puerto (CONAGUA, 2012), there is a distinct pattern of low rainfall from December through April followed by an increase until September and then a decrease through December. Considering our results in the context of prevailing rainfall trends, sowing a month or two after the beginning of the rainy season should result in better seed survival than sowing early in the season. The cost of such a strategy is to reduce the growing time available for the seedlings before the dry season, which normally results in increased seedling mortality because the seedlings are smaller. Another option could be to use seeds that are very close to germination, which would give them a longer growing season and a higher probability of surviving their first dry season.

The two SBA fields that had statistically higher seed survival rates were farther (153 and $163 \mathrm{~m}$ ) from the forest edge than the third field $(0 \mathrm{~m})$. One could expect that predators, especially rodents, would be more common in the forest (Mari et al., 2008) than in the relatively open land of a SBA field. Madsen and Löf (2005) found that intensive site preparation where slash was completely removed from regeneration areas substantially reduced predation in oak relative to predation in uncleared areas. The way SBA is practiced in Quintana Roo requires that the plots are slashed every year, so they always start from an open field needed for full sun over the crops. Because there were only three fields, we must be cautious in interpreting the effects of distance from forest, but our results could indicate that mahogany seeds would need to be sown at a higher rate near forest edges than away from the edges to achieve a more uniform distribution of mahogany trees and adequate stock levels near the forest edge.

The study was established at the beginning of the rainy season, when seeds were thought to have the best conditions to germinate naturally. Mahogany seed requires about 28 days to germinate after absorbing sufficient moisture, usually supplied by the first rain event. If moistened 
seeds could be protected with the full enclosure for 28 days (the time for seeds to germinate after being moistened) our results suggest that on average $54 \%\left(=0.989^{56} \times 100\right)$ of the seeds would survive to germinate, assuming a constant survival rate per 12 -hours period. But seeds available to small mammals, insects, or all predators averaged $93 \%$ chance of not being partially consumed or removed in 12 hours; thus, only $1.7 \%$ would survive for 28 days. Such a low rate is unacceptable, as it would require large quantities of seeds to produce a reasonable number of seedlings per hectare and likely result in a poor spatial distribution of mahogany. One way to improve the odds that a seed will germinate and form a seedling is to reduce the number of days that the seed is vulnerable to partial consumption or removal by seed predators. Pre-moistening seeds before sowing reduces the number of days to germination for some tree species (William, 1986). A study involving irrigation of mahogany seed suggests that presoaking could reduce the number of days to germination of sown seed (Morris et al., 2000). Assuming the reduction in number of days to germination equals the number of days of soaking, sowing seeds that had been moistened 14 days before sowing, our model predicts that $13 \%\left(=0.93^{28} \times 100\right)$ would survive to germinate. After soaking for 21 days, $36 \%$ of the seeds are predicted to survive to germinate. Both estimates are based on the assumption that the probability of being partially consumed or removed is independent from one 12 -hours period to the next and that seeds that have been moistened for a few weeks are as likely to be partially consumed or removed as ones that have only recently been moistened. Studies are needed to quantify the relationship between the number of days of presoaking and the number of days after sowing to germination. To develop recommendations for sowing, we assume that $58 \pm 2 \%$ of seeds germinate (mean \pm SE; Morris et al., 2000) and $40 \%$ of germinated seedlings survive to 48 months (Negreros-Castillo et al., 2003). A goal of 100 4-years-old mahogany seedlings per hectare is proposed here as reasonable for a managed tropical forest in which maintaining biodiversity is a priority. Figure 4 shows the number of seeds that would need to be sown per hectare in relation to the number of days seeds were soaked before sowing to yield 100 mahogany seedlings per hectare assuming rates of seed survival we documented (i.e., $93 \pm 1 \%$ per half-day).

We have so far assumed constant rates of seed removal and damage over time. It is possible that there is a nonlinear relationship between seed removal and time, but we were unable to test for this within the constraints of the study. Rates of seed removal/damage could decrease over time if local predators are satiated, if search time by predators for mahogany seeds increases as local seed density declines (Werner and Hall, 1974), or if predators switch to more abundant prey as mahogany seed density declines (Veech, 2001). Alternatively, seed removal/damage could increase if the density of mahogany seed predators increases over time, the search efficiency of predators increases with experience (Pietrewicz and Kamil, 1979) or predators disproportionately select mahogany seeds as it becomes rarer (i.e., negative frequency-dependent selection; Greenwood, 1985).
Slash and burn agriculture (SBA) has been extensively studied (Ford and Nigh, 2010), and its role in current forest structure has been acknowledged (Edwards, 1986). Unfortunately, its potential use as a silvicultural technique for the regeneration of important commercial timber species has been overlooked; instead, efforts to reduce the use of SBA have been the focus of several studies and research institutes (Palm et al., 2013). Some other studies have demonstrated the favorable conditions provided by SBA in the regeneration of Brazil nut (Bertholletia excels) (Cotta et al., 2008), but efforts are still needed to make SBA a viable silvicultural technique. More studies are needed to evaluate the effect of distance from the forest edge and to compare survival of seed not soaked before sowing to seed soaked for 1-4 weeks, but our results suggest that direct sowing of SBA fields that are being abandoned for their fallow period may be a viable silvicultural technique to regenerate tropical forests in Quintana Roo and Central America that can be used immediately. This method has already been recommended in the Silvicultural Guide of the Mahogany Forests of Quintana Roo (Negreros-Castillo et al., 2015).

\section{Acknowledgments}

We thank the Sociedad de Productores Forestales de la Zona Maya for providing the facilities needed for the field work and information provided during the study. We are grateful to Ing. Victoria Santos Ledezma and Ing. Rosa Ledezma for their support with the project, the people of ejido Betania for their support during the field work, and Dr. Rafael Flores Peredo for helping design the experiment. Financial support for the field work of this research was provided by Universidad Veracruzana and Colegio de la Frontera Sur (Chetumal). Comments by two anonymous reviewers improved the manuscript.

\section{References}

Bautista F., ZinckJ. A., 2010. Construction of a Yucatec Maya soil classification and comparison with the WRB framework. Journal of Ethnobiology and Ethnomedicine, 6:7. DOI:10.1186/1746-4269-6-7.

Brooks S. P., Gelman A., 1998. General methods for monitoring convergence of iterative simulations. Journal of Computational and Graphical Statistics, 7 (4): 434-455.

Brown N., Jennings S., Clements T., 2003. The ecology, silviculture and biogeography of mahogany (Swietenia macrophylla): a critical review of the evidence. Perspectives in Plant Ecology, Evolution and Systematics, 61 (1/2): 37-49.

Cole R. J., 2009. Postdispersal seed fate of tropical montane trees in an agricultural landscape, southern Costa Rica. Biotropica, 41 (3): 319-327.

CONAGUA, 2012. Comisión Nacional del Agua. Servicio metereológico Nacional. Estación Felipe Carrillo Puerto. Q Roo.

Cotta J. N., Kainer K. A., Wadt L. H., Staudhammer C. L., 2008. Shifting cultivation effects on Brazil nut (Bertholletia excelsa) regeneration. Forest Ecology and Management, 256 (1): 28-35. 
Dawkins H. C., Philip M. S., 1998. Tropical moist forest silviculture and management: a history of success and failure. Oxon, U.K., New York, CAB International.

Edwards C. R., 1986. The human impact on the forest in Quintana Roo, Mexico. Journal of Forest History, 30: 120-127.

Fedriani J. M., Manzaneda A. J., 2005. Pre-and postdispersal seed predation by rodents: balance of food and safety. Behavioral Ecology, 16 (6): 1018-1024.

Ford A., Nigh R., 2010. The milpa cycle and the making of the Maya forest garden. Research Reports in Belizean Archaeology, 7: 183.

Fredericksen T. S., Putz F. E., 2003. Silvicultural intensification for tropical forest conservation. Biodiversity and Conservation, 12 (7): 1445-1453.

García E., 1973. Modificaciones al sistema de clasificación climática de Köppen (para adaptarlo a las condiciones de la República Mexicana). Instituto de Geografía. UNAM.

Gelman A., Meng X. L., Stern H., 1996. Posterior predictive assessment of model fitness via realized discrepancies. Statista Sinica, 6 (4): 733-760.

Gelman A., Hill J., 2007. Data analysis using regression and multilevel/hierarchical models. Cambridge University Press.

Greenwood J. J. D., 1985. Frequency-dependent selection by predators. Oikos, 44: 195-210.

Gutiérrez-Granados G., Juárez V., Alcalá R. E., 2011. Natural and human disturbances affect natural regeneration of Swieitenia macrophylla: implication for rainforest management. Forest Ecology and Management, 262:161-169.

INEGI, 2013. Anuario estadístico y geográfico de los Estados Unidos Mexicanos (317.2). Instituto Nacional de Estadística y Geografía (México).

Janzen D. H., 1971. Seed predation by animals. Annual Review of Ecology and Systematics, 2: 465-492.

Lamb F. B., 1966. Mahogany of tropical America: Its ecology and management. University of Michigan.

Lichti N. I., Steele M. A., Zhang H., Swihart R. K., 2014. Mast species composition alters seed fate in North American rodent-dispersed hardwoods. Ecology, 95: 1746-1758.

Madsen P., Löf M., 2005. Reforestation in southern Scandinavia using direct seeding of oak (Quercus robur L.). Forestry, 78 (1): 55-64.

Mari L., Casagrandi R., Gatto M., Avgar T., Nathan R., 2008. Movement strategies of seed predators as determinants of plant recruitment patterns. American Naturalist, 172 (5): 694-711.

Mayhew J. E., Newton A. C., 1998. The Silviculture of Mahogany. Institute of Ecology and Resource Management. University of Edinburgh, $C A B$ International.

Meléndez-Ackerman E., Calisto-Pérez C., Morales-Vargas M., Fumero-Cabán J., 2003. Post-hurricane recovery of an herbaceous understory plant in a tropical rain forest in Puerto Rico. Journal of Tropical Ecology, 19: 677-684.

Morris M. H., Negreros-Castillo P., Mize C., 2000. Sowing date, shade, and irrigation affect big-leaf mahogany (Swietenia macrophylla King). Forest Ecology and Management, 132 (2): 173-181.

Myster R. W., 2015. Seed predation, pathogens and germination in primary vs. secondary cloud forest at Maquipucuna Reserve, Ecuador. Journal of Tropical Ecology, 31: 375-378.

Navarro-Cerrillo R. M., Griffith D. M., Ramírez-Soria M. J., Pariona W., Golicher D., Palacios G., 2011. Enrichment of big-leaf mahogany (Swietenia macrophylla King) in logging gaps in Bolivia: The effects of planting method and silvicultural treatments on long-term seedling survival and growth. Forest Ecology and Management, 262 (12): 2271-2280.

Negreros-Castillo P., Cámara-Cabrales L., Devall M. S., Fajvan M. A., Mendoza Briseño M. A., Mize C. W., Navarro-Martínez A., 2015. Silviculture guide for the mahogany forests of Quintana Roo, Mexico. North American Forestry Commission. USFS-FAO.
Negreros-Castillo P., Mize C., 2003. Enrichment planting of Swietenia macrophylla (big leaf mahogany) and Cedrela odorata (Spanish cedar) in Quintana Roo, Mexico. In: Lugo A. E., Figueroa Colon J. C., Alayon M. (Eds), Big-Leaf Mahogany: Genetics, Ecology, and Mangement., Ecological Studies, vol. 159, Springer-Verlag, New York, p. 278-287.

Negreros-Castillo P., Snook L., Mize C. W., 2003. Regenerating mahogany (Swietenia macrophylla) from seed in Quintana Roo, Mexico: the effects of sowing method and clearing treatment. Forest Ecology and Management, 183 (1-3): 351-362.

Nopp-Mayr U., Kempter I., Muralt B., Gratzer G., 2012. Seed survival on experimental dishes in a central European old-growth mixed-species forest - effects of predator guilds, tree masting and small mammal population dynamics. Oikos, 121: 337-346.

Norghauer J. M., Newbery D. M., 2011. Seed fate and seedling dynamics after masting in two African rain forest trees. Ecological Monographs, 81: 443-469.

Nyland R. D., 2002. Silviculture: Concepts and Applications. Waveland Press Inc., Illinois, $682 \mathrm{p}$.

Palm C. A., Vosti S. A., Sanchez P. A., Ericksen P. J. (Eds), 2013. Slash-and-burn agriculture: the search for alternatives. Columbia University Press.

Pennington T. D., Sarukhan J., 2005. Árboles tropicales de México. UNAM y Fondo de Cultura Economica, México D.F.

Pérez-Ramos I. M., Marañón T., 2008. Factors affecting post-dispersal seed predation in two coexisting oak species: microhabitat, burial and exclusion of large herbivores. Forest Ecology and Management, 255 (8-9): 3506-3514.

Pietrewicz A. T., Kamil A. C., 1979. Search image formation in the blue jay (Cyanocitta cristata). Science, 204: 1332-1333.

Plummer M., 2003. JAGS: A program for analysis of Bayesian graphical models using Gibbs sampling. In: Proceedings of the 3rd International Workshop on Distributed Statistical Computing, p. 20-22.

R. Core Development Team, 2013. R: A language and environment for statistical computing. Vienna, Austria. http://www.R-project.org Smith D. M., Larson B. C., Kelty M. J., Ashton P. M. S., Bowersox T. W., 1997. The Practice of Silviculture: Applied Forest Ecology. John Wiley and Sons.

Snook L. K., 1993. Stand dynamics of mahogany (Swietenia macrophylla King) and associated species after fire and hurricane in the tropical forests of the Yucatan Peninsula Mexico. Dissertation, Yale University.

Sorensen N., 2006. Regeneration and growth of several canopy tree species in the Maya forest of Quintana Roo, Mexico: The role of competition and microhabitat conditions. Dissertation, Oregon State University.

Su Y., Yajima M., 2012. R2jags: A Package for Running jags from R. $\mathrm{R}$ package version 0.03-08, URL http://CRAN. R-project. org/package $=$ R2jags

Veech J. A., 2001. The foraging behavior of granivorous rodents and short-term apparent competition among seeds. Behavioral Ecology, 12: 467-474.

Werner E. E., Hall D. J., 1974. Optimal foraging and the size selection of prey by the bluegill sunfish (Lepomis macrochirus). Ecology, 55: $1042-1052$

William R. L., 1986. A guide to forest seed handling with special reference to the tropics. FAO, Forestry Paper 20/2, 392 p. 